\title{
A Review on Effective Approach of Biogenic Metal Nanoparticles Contrary to Obesity
}

\author{
Prince Chawla*, Mukul Kumar and Huma Khan \\ School of Bioengineering and Food Technology, Shoolini University, India
}

Submission: May 14, 2018; Published: May 25, 2018

*Corresponding author: Prince Chawla, School of Bioengineering and Food Technology, Shoolini University, Solan, Himachal Pradesh, India, Email: princefoodtech@gmail.com

\begin{abstract}
Obesity is considered as chronic disorder which ultimately results into several life frightening diseases. Several weight loss drugs are existing in market but these are reckless due to undesirable side effects on human body. Natural herbs and plant based bioactive components are showing promising results to cure the obesity at large extent. Although bioactive components have vital application but inhibitor factors reduce their mode of action against obesity. Therefore, nanoparticles in treatment of obesity play a vital role due to their ability to unreceptively or vigorously target the organs or tissues of interest, respectively. The aim of this review is to represent the current approach of biogenic metal nanoparticles capped with bioactive components to eliminate the obesity at large extent.
\end{abstract}

Keywords: Obesity; Nanoparticles; Biogenic; Herbs; Bioactive

\section{Introduction}

World's population is increasing enormously day by day and people of every age group are suffering from obesity $[1,2]$. Obesity is always categorized by excess of human body fat and it is deliberated as severe multi-functional ailment [3-5]. Several life threatening diseases are directly associated with obesity and if it persist severely by the similar frequency, with in upcoming ten years population of 2.16 billion people (i.e. $40 \%$ of the global population) could be overweight and 1.2 billion people ( $20 \%$ of the world's population) could be obese [5-7]. To combat with obesity and disease associated with it, several researchers explored numerous effective therapies and both allopathic and plant based drugs [8-12]. Apart from effectiveness of respective drugs people are fronting several side effects and life frightening disorders [13]. Furthermore, due to altering life style of modern society people want effective results with less affords, therefore to overcome this delinquent, approach of biogenic nanoparticles gained candidature of interest at large extent without any further side effects [14-20]. Metal nanoparticles are effective nano-technological tool which can be synthesized using several methods and processes. Green synthesis of nanoparticles attained more prevalence due to their non-toxic effect upon human body $[16,17]$. Nano particles have remarkable tendency to carry the anti-obesity bioactive components of the plants and herbs at targeted areas $[15,16]$. Therefore, this mini review is more emphasized upon influence of biogenic nanoparticles on obesity. Plants used in synthesis of nanoparticles, synthesis of biogenic nanoparticles and mechanism of nanoparticles against obesity are conferred.

\section{Discussion}

Among prominent classes of nanoparticles metal nanoparticles accomplished significant consideration from scientific community of modern day's science [21]. For the synthesis of nanoparticles noble metals like $\mathrm{Au}$ (gold), $\mathrm{Ag}$ (silver), Pd (palladium), Zn (zinc), Cu (copper), Fe (iron) are used due to their unique $\mathrm{d}$ - $\mathrm{d}$ transition characteristics and high Localized Surface Plasmon Resonances phenomena [22]. Synthesis of nanoparticles with their vital properties such as high monodispersity and biocompatibility with other component is required for a wide range of applications from environment to biomedics [23]. In past few years there has been noteworthy upsurge in the arena of fabrication of nanoparticles with meticulous size and morphologies with unique features [15$17,23]$. Owing to fact that distant from their potential physical and chemical properties nanoparticles are connective links between large size bulk materials and molecular level edifices, hence nanoparticles have already achieved remarkable level in every aspect of modern science with vital application such as catalysis, electrochemistry, biotechnology, molecular biology medical and trace element detection, respectively [21-23]. Apart from several existing methods of synthesis of nanoparticles green synthesis of nanoparticle is most abundantly used process 


\section{Current Research in Diabetes \& Obesity Journal}

and suitable for human as well all living creatures. Several biological approaches including beneficial microorganisms are also used for fabrication of the metal nanoparticles [24,25]. Moreover, coating of biological materials and plant based components over charged nanoparticles make them more biocompatible which are most significant tool in biomedicines and its related fields. In pharmacological applications biogenic synthesis of gold and silver nanoparticles make them suitable candidate to cure several diseases [17-22]. In this context extracts from various plant parts such as root, seed, leaf, latex are used as fabrication of nanoparticles as their components act as reducing and capping agents. Using plant extracts shapes, size and morphological behavior (triangular, hexagonal and spherical) could be controlled and desirable results can also be attained $[14,17,19]$.

Several studies already explored numerous herbs have remarkable tendency to cure obesity at large extent. Bio active components present in plant extracts directly stimulate the metabolic process of human body and also inhibit further synthesis or saturation of fats in adipose tissues. Several herbs such as Nigella sativa, Opuntiaficus indica, Trigonellafoenum graecum, Hibiscus sabdariffa, Lycium barbarum, Bauhinia variegate, Borhavia diffura, Bosewellia serrata, Clerodendrum multiflorum, Embelia ribes, Glycyrrhiza glabra, Gymnema sylvestre are used as anti-obesity herbs $[12,26]$. Scientific studies explored direct effect of the bioactive components and minerals present in the extracts upon body weight, body mass index or waist circumference and waist to hip ratio, respectively [6]. Obesity reducing mechanisms for these herbs involved decline in fat or lipid absorption, reduced calories intake by gastrointestinal tracts, better calories disbursement, reduced pre-adipocyte differentiation and proliferation, or decreased lipogenesis and increased lipolysis. Reduced energy ingestion from gastrointestinal tracts is instigated by the bioactive components of the herbs by acting on pancreatic lipase which ultimately leads to weight loss. Although bioactive components are more reliable for curing of obesity at large extent, but several inhibitory factors decrease their productivity against obesity in human body system. Therefore, nanoparticles in treatment of obesity play a vital role due to their ability to passively or actively target the organsor tissues of interest, respectively. In passive type of targeting mechanism metal nanoparticles capped with bioactive component accumulate in areas around the stored fat in tissues which is known as enhanced permeation and retention. For intracellular localization of the anti-obesity bioactive component unambiguous interaction between the carrier nanoparticles and target cells occurs through specific ligand receptor and cellular recognition in active type of targeting $[26,27]$. Active type of targeting is always based upon the size of the nanoparticles and this could be attained by the capping of bioactive components of the plant extracts [15-17]. This surface modification of nanoparticles divulge specificity for targeting cells [24]. Hence biogenic metal nanoparticles could overcome the obesity of the enormous population affecting from it and also could take place in better weight management system.

\section{Conclusion}

Obesity is an enduring disorder that distresses billion of the people globally which ultimately influence the generous morbidity and mortality. Natural bioactive components derived from the herbs and plants could be a better and safer approach as compared to existing drugs to cure the obesity. Biogenic metal nanoparticles capped with bioactive analyte exhibit potential action in treatment of the obesity. Apart from anti-obesity application nanoparticles capped with bioactive components also act as body cleanser, liquefy fat in body, help to eradicate desire of food, stimulate glandular exudations, and reduce water retention, boot energy. With effective exercise and intake of nanoparticles result in synergistic and improved effects.

\section{References}

1. Xue Y, Xu X, Zhang XQ, Farokhzad OC, Langer R (2016) Preventing diet-induced obesity in mice by adipose tissue transformation and angiogenesis using targeted nanoparticles. Proc Natl Acad Sci USA 113(20): 5552-5557.

2. FAO (2017) The future of food and agriculture: Trends and challenges.

3. Derdemezis CS, Voulgari PV, Drosos AA, Kiortsis DN (2011) Obesity, adipose tissue and rheumatoid arthritis: coincidence or more complex relationship. Clin Exp Rheumatol 29(4): 712-727.

4. Withrow D, Alter DA (2011) The economic burden of obesity worldwide: a systematic review of the direct costs of obesity. Obes Rev 12(2): 131-141.

5. Peters U, Dixon AE, Forno E (2018) Obesity and asthma. Journal of Allergy and Clinical Immunology 141(4): 1169-1179.

6. Singh RK, Kumar P, Mahalingam K (2017) Molecular genetics of human obesity: A comprehensive review. C R Biol 340(2): 87-108.

7. Kelly T, Yang W, Chen CS, Reynolds K, He J (2008) Global burden of obesity in 2005 and projections to 2030. Int J Obes (Lond) 32(9): 1431-1437.

8. Liu RH (2003) Health benefits of fruit and vegetables are from additive and synergistic combinations of phytochemicals. Am J Clin Nutr 78(3 Suppl): 517S-520S.

9. Rayalam S, Della Fera MA, Baile CA (2008) Phytochemicals and regulation of the adipocyte life cycle. J Nutr Biochem 19(11): 717-726.

10. Santos AP, Rogero MM, Bastos DH (2010) Edible plants, their secondary metabolites and antiobesogenic potential. Recent Pat Food Nutr Agric 2(3): 195-212.

11. Rocca A, Moscato S, Ronca F, Nitti S, Mattoli V, et al. (2015) Pilot in vivo investigation of cerium oxide nanoparticles as a novel anti-obesity pharmaceutical formulation. Nanomedicine 11(7): 1725-1734.

12. Mohamed GA, Ibrahim SR, Elkhayat ES, El Dine RS (2014) Natural antiobesity agents. Bulletin of Faculty of Pharmacy, Cairo University 52(2): 269-284.

13. Moldovan B, David L, Achim M, Clichici S, Filip GA (2016) A green approach to phytomediated synthesis of silver nanoparticles using Sambucusnigra L. fruits extract and their antioxidant activity. Journal of Molecular Liquids 221: 271-278.

14. Sharma D, Kanchi S, Bisetty K (2015) Biogenic synthesis of nanoparticles: A review. Arabian Journal of Chemistry. 


\section{Current Research in Diabetes \& Obesity Journal}

15. Sangaonkar GM, Pawar KD (2018). Garcinia indica mediated biogenic synthesis of silver nanoparticles with antibacterial and antioxidant activities. Colloids Surf B Biointerfaces 164: 210-217.

16. Sharmila G, Pradeep RS, Sandiya K, Santhiya S, Muthukumaran C, et al. (2018) Biogenic synthesis of $\mathrm{CuO}$ nanoparticles using Bauhinia tomentosa leaves extract: Characterization and its antibacterial application. Journal of Molecular Structure 1165(5): 288-292.

17. Gopinath V, Priyadarshini S, Loke MF, Arunkumar J, Marsili E, et al. (2015) Biogenic synthesis, characterization of antibacterial silver nanoparticles and its cell cytotoxicity. Arabian Journal of Chemistry.

18. Gudikandula K, Vadapally P, Charya MS (2017). Biogenic synthesis of silver nanoparticles from white rot fungi: Their characterization and antibacterial studies. Open Nano 2: 64-78.

19. Firdhouse MJ, Lalitha P (2016) Biogenic silver nanoparticles-Synthesis, characterization and its potential against cancer inducing bacteria Journal of Molecular Liquids 222: 1041-1050.

20. Agarwal H, Kumar SV, Rajeshkumar S (2017) A review on green synthesis of zinc oxide nanoparticles-an eco-friendly approach Resource-Efficient Technologies.

21. Wu S, Li D, Wang J, Zhao Y, Dong S, et al. (2017) Gold nanoparticles dissolution based colorimetric method for highly sensitive detection of organophosphate pesticides. Sensors and Actuators B: Chemical 238 427-433.
22. Lee MG, Patil V, Na YC, Lee DS, Lim SH, et al. (2018) Highly stable, rapid colorimetric detection of carbaryl pesticides by azo coupling reaction with chemical pre-treatment. Sensors and Actuators B: Chemical 261: 489-496.

23. Kumar N, Seth R, Kumar H (2014) Colorimetric detection of melamine in milk by citrate-stabilized gold nanoparticles. Anal Biochem 456: 4349.

24. Mudshinge SR, Deore AB, Patil S, Bhalgat CM (2011) Nanoparticles: emerging carriers for drug delivery. Saudi Pharm J 19(3): 129-141.

25. Das S, Parida UK, Bindhani BK (2013) Green biosynthesis of silver nanoparticles using Moringa Oleifera leaf. Int J Nanotechnol Appl 3: $51-62$

26. Hasani Ranjbar S, Jouyandeh Z, Abdollahi M (2013) A systematic review of anti-obesity medicinal plants-an update. J Diabetes Metab Disord 12(1): 28

27. Fang JY, Al Suwayeh SA (2012) Nanoparticles as delivery carriers for anticancer prodrugs. Expert Opin Drug Deliv 9(6): 657-669.

Your next submission with Juniper Publishers will reach you the below assets

- Quality Editorial service

- Swift Peer Review

- Reprints availability

- E-prints Service

- Manuscript Podcast for convenient understanding

- Global attainment for your research

- Manuscript accessibility in different formats ( Pdf, E-pub, Full Text, Audio)

- Unceasing customer service

Track the below URL for one-step submission https://juniperpublishers.com/online-submission.php 